\title{
A Map Based Inventory of Lakes in Nepal
}

\author{
Ukesh Raj Bhuju, Madhukar Khadka, Pawan Kumar Neupane and \\ Radium Adhikari \\ National Lakes Conservation Development Committee, Dillibazar, Kathmandu
}

\begin{abstract}
An inventory of lakes in Nepal based on desktop study of topographic maps published between 1992 and 2001 was produced, as a part of the National Lake Strategic Plan for Nepal. As all earlier studies reported only partially the number of lakes in the Terai and the high mountains, the scope of this study was to produce a complete list of lakes useful in planning for lakes conservation and management. Closed water bodies indicated in the topographical sheets were considered as lakes. The inventory included name, location, altitude, grids X and Y, and sheet number. An alpha-numerical code was generated to identify lakes by districts. The study also included surveillance with 121 researchers in the team representing Nepal Academy of Science and Technology, National Trust for Nature Conservation and Tribhuvan University - Central Department of Environmental Science. They gathered photographic evidences and some geographical information of 229 lakes in 49 districts from August through October 2009. They also consulted with over 1,700 stakeholders through focus group discussions and consultation meetings in the districts for the strategic plan. A list of 5,358 lakes has been prepared. Of the 75 districts, 74 contain lakes. There are 21 districts containing less than nine lakes in each, and 16 districts containing over 100 lakes in each. Among the rest of the districts, 16 contain 10 to 29 lakes, and 22 contain 30 to 99 lakes. The eight districts containing high number of lakes are Humla (381), Taplejung (380), Kapilbastu (351), Solukhumbu (339), Rupandehi (289), Banke (243), Dhanusa (230), and Dolpa (210). Altitudewise, 2,712 lakes (51\%) are distributed below 500m, and 2,227 (42\%) above 3,000m. Only 419 lakes ( $<8 \%$ ) are in the mid hills of altitudinal range between $500 \mathrm{~m}$ and 2,999m. Names are available only for 472 lakes in the topographical sheets. The lists of lakes are maintained at the National Lake Conservation Development Committee and its key partner institutions. The significant lakes included the largest Rara lake (800ha), and the longest Phoksundo lake (5.15km), and the highest placed Dhau Dhundhun Tal (5,905m).
\end{abstract}

Key words: lake, inventory, topographical sheet

\section{Introduction}

The National Lake Strategic Plan for Nepal was felt essential to materialize the vision, goal and objectives of the National Lake Conservation Development Committee (NLCDC) that was established under the aegis of the Ministry of Tourism and Civil Aviation by using the provisions made in the 1957 Development Committee Act on March 23, 2007.

The primary objective of NLCDC was to conserve and develop the lakes of the country, and its scope included policy advice to the government on lakes conservation and development, program planning and implementation in coordination with the sectoral ministries, develop lakes as tourism destinations, public awareness on the cultural and religious significances of lakes, protect the lakes from pollution, encroachment and other detrimental activities, etc.

At the time when the strategic plan was conceptualized in 2009, it was realized that the initial task should be to prepare an inventory of the lakes. Although there were three notable works on lakes inventory undertaken earlier, they need to be updated in terms of recent information and geographical coverage. According to the DOAD (1993) reports, there are around 5,000 lakes, 1,380 reservoirs, and 5,183 village ponds in the country. According to IUCN inventory (1996), there are 163 wetlands in Terai, and 79 in the hills and mountains. Similarly, 3,252 glaciers and 2,323 glacial lakes have been identified in the high mountain 
region (Mool et al. 2001). The inventory of glacial lakes was conducted from the perspectives of the potential Glacial Lakes Outburst Floods (GLOF).

Considering the urgency of the strategic plan, and also realizing the long duration of time for undertaking field inventory of lakes, it was decided to go for an alternative ways of lakes inventory. Upon exploration of possible alternatives, the strategic plan team decided to undertake a map based inventory. There are two major types of maps being used for planning purposes. They are district maps and topographical sheets.

Initially the district maps (scale of 1:125,000) were considered to be useful to identify major lakes. However, it was found that the district maps published between
1993 and 2007 were not completely reliable since numerous lakes were not shown in those maps. For example, the district maps of 21 districts did not even mention any lake, whereas the topographical sheets of the same districts revealed as many as 1,400 lakes (Table 1 ).

The entire area of the country is covered with 706 topographical sheets that were produced using the latest technology and information. Published between 1992 and 2001, the topographic sheets are the most frequently used base maps for the country. The Terai and midmountain regions are covered with 590 sheets of 1:25,000 scale, and the High Mountain and Himalayan regions with 116 sheets of 1:50,000 scale. Each sheet is identified using an index map (Fig. 1).

Table 1. Number of lakes in the selected districts

\begin{tabular}{ll|l|ll|c}
\hline Districts* & Number of lakes** & \multicolumn{2}{|c|}{ Districts* } & Number of lakes** \\
\hline 1. & Baitadi & 1 & 2. & Lalitpur & 3 \\
3. & Banke & 243 & 4. & Mahottari & 186 \\
5. & Bara & 93 & 6. & Myagdi & 33 \\
7. & Bhaktpur & 2 & Nawalparasi & 163 \\
9. & Chitawan & 40 & 10. & Parsa & 71 \\
11. & Dailekh & 7 & 12. & Saptari & 46 \\
13. & Darchula & 19 & 14. & Sarlahi & 74 \\
15. & Dhanusa & 16. & Sindhuli & 9 \\
17. & Jajarkot & 230 & 18. & Siraha & 140 \\
19. & Kalikot & 16 & 20. & Surkhet & 22 \\
21. & Kavrepalanchok & 1 & Total & $\mathbf{1 4 0 0}$ & \\
\hline
\end{tabular}

*No lake was mentioned in the district maps ** As shown in the topographical sheets

These are accurate maps which are also available in digital forms. They contain eight basic layers that are essential for field level planning. The layers are: Administrative boundaries (Village Development Committee, Municipalities, District Development Committee), Building (settlements etc),Contours (20 m intervals), Designated area (national park etc), Hydrographic (lake, river, canal, glacier, etc), Land cover (rocks, cultivation, forest types, orchard, swamp etc), Transportation (roads etc),Utility (school, hospital, bus terminal, monument, etc).

\section{Methodology Defining lakes}

For the purpose of this inventory, water bodies indicated in the topographical sheets were considered as lakes although they were less than one hectare in area. There are several definitions of lakes, and they vary according to their purposes and scopes of studies. Lakes greatly vary in size. Of an estimated 304 million standing water bodies worldwide, $91 \%$ are one hectare or less in area (Downing et al. 2006). One definition of "lake" it is that is a body of water of two hectares (five acres) or more in area, however, others have defined lakes as water bodies of five hectares (12 acres) and above, or eight hectares (20 acres) and above. Charles Elton, one of the founders of ecology, regarded lakes as water bodies of 40 hectares (99 acres) or more (Answers Corporation 2009). Another criterion that was referred to was the shape of a water body. The water bodies having natural shapes were considered as lakes. The artificial fishery ponds and the water bodies having rectangular shapes were considered man-made and hence not included in the list of lakes (Fig.1). 


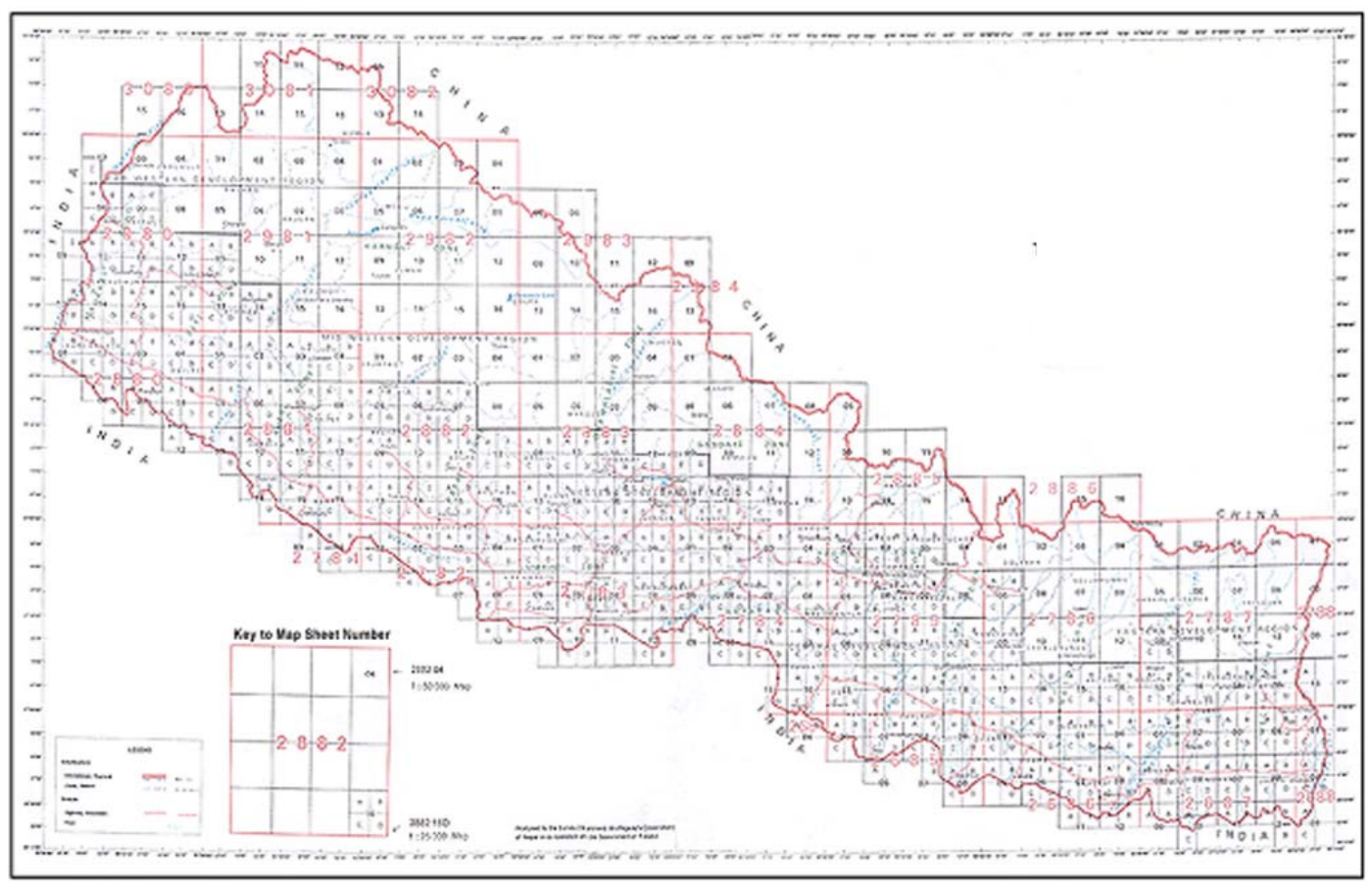

Fig. 1. Topographic Base map of Nepal

\section{Basic Information of Lakes}

The following basic information derived from the topographical sheets included: name of the lake (where available), district of location, altitude (on the basis of the contour lines), grids $\mathrm{X}$ and $\mathrm{Y}$ (instead of latitude and longitude), topographical sheet number.

An alpha-numerical code was generated to identify lakes by districts. The first two alphabets indicate the name of a district, and the subsequent numbers indicate the serial number within the district. Thus, the code numbers indicate both the number of lakes and name of a district in which they contain.

Upon knowing the location of the lakes, additional information could be collected from the topographical sheets. As mentioned earlier, the eight layers of the sheets include administrative boundaries, transportation, settlements, land cover, other hydrographic data, altitude, utility, and designated areas.

\section{Field Validation}

The districtwise information of the lakes was also verified during field observations and consultations in 49 districts during August through October 2009. The field observations were parts of the strategic planning process. The two main aspects that were considered for field observations were:

1. Photographic evidences of landscapes, tangible and intangible heritage, rituals, socio-economic aspects, usage of lake resources, ecological and environmental components of lakes and so on.

2. Textual documentation and mapping of lakes including vegetation types, floral and faunal distribution, geographical locations for references research and monitoring, water quality and quantity, lake resources, etc.

The above mentioned points were presented and discussed in the pre-field one day workshops for the researchers. Among the 121 persons who conducted field works were senior researchers and field assistants representing Nepal Academy of Science and Technology (NAST) (38) and National Trust for Nature Conservation (NTNC) (29), and four faculty members and 50 master level students of environmental science representing Tribhuvan University, Central Department of Environmental Science (TU-CDES). They conducted rapid ecological surveys (CBD 2006) of 229 lakes, and 
gathered information including photographic evidences in 49 districts. They also conducted 97 focus group discussions in the communities around the lakes, and 49 consultation meetings in the district headquarters where over 1,700 participants shared their views.

\section{Lakes Distributions}

A list of 5,358 lakes has been prepared using the topographical sheets, whereas only 278 lakes were identified from the district maps (Table 1).

Table 1. Number of lakes by districts, phytogeographical regions, and ecological zones

\begin{tabular}{|c|c|c|c|c|c|c|c|c|c|}
\hline \multirow{2}{*}{$\begin{array}{l}\text { Phytogeo- } \\
\text { graphical regions } \\
\text { Ecological zones }\end{array}$} & \multicolumn{3}{|c|}{ Western $\left(<8^{0} 00^{\prime} \mathrm{E}\right)$} & \multicolumn{3}{|c|}{ 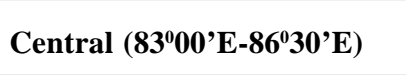 } & \multicolumn{3}{|c|}{ Eastern (> 86 $\left.{ }^{0} 30^{\prime} E\right)$} \\
\hline & Districts & $\mathrm{D}$ & $\mathrm{T}$ & Districts & $\mathrm{D}$ & $\mathrm{T}$ & Districts & $\mathrm{D}$ & $\mathrm{T}$ \\
\hline \multirow{9}{*}{ 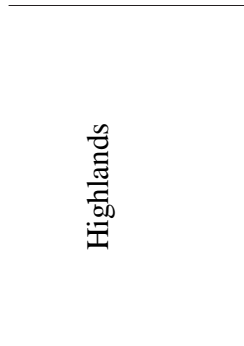 } & Districts & $\mathrm{D}$ & $\mathrm{T}$ & Districts & $\mathrm{D}$ & $\mathrm{T}$ & Districts & $\mathrm{D}$ & $\mathrm{T}$ \\
\hline & Jumla & 11 & 99 & Dolakha & 5 & 42 & Taplejung & 12 & 380 \\
\hline & Kalikot & - & 1 & Sindhupalchok & 6 & 75 & Sankhuwasabha & 15 & 159 \\
\hline & Mugu & 16 & 125 & Rasuwa & 5 & 38 & Solukhumbu & 32 & 339 \\
\hline & Humla & 2 & 381 & Manang & 1 & 66 & & & \\
\hline & Bajura & 1 & 57 & Mustang & 25 & 78 & & & \\
\hline & Bajhang & 2 & 25 & Dolpa & 6 & 210 & & & \\
\hline & Darchula & - & 19 & & & & & & \\
\hline & 7 & 32 & 707 & 6 & 48 & 509 & 3 & 59 & 878 \\
\hline \multirow{21}{*}{ 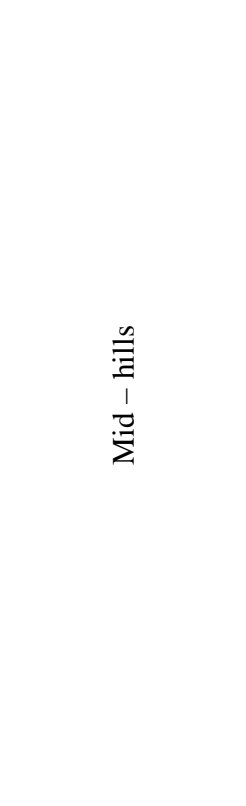 } & Pyuthan & 2 & 19 & Sindhuli & - & 9 & Panchthar & 4 & 17 \\
\hline & Rolpa & 1 & 16 & Ramechhap & 4 & 25 & Ilam & 5 & 30 \\
\hline & Rukum & 1 & 70 & Kavrepalanchok & - & 1 & Dhankuta & 1 & 4 \\
\hline & Salyan & 2 & 5 & Lalitpur & - & 3 & Terhathum & 5 & 4 \\
\hline & Surkhet & - & 22 & Bhaktpur & - & 2 & Bhojpur & 5 & 7 \\
\hline & Dailekh & - & 7 & Kathmandu & 2 & 1 & Okhaldhunga & 2 & 0 \\
\hline & Jajarkot & - & 16 & Nuwakot & 2 & 3 & Khotang & 7 & 10 \\
\hline & Achham & 6 & 13 & Dhading & 2 & 5 & Udayapur & 3 & 14 \\
\hline & Doti & 1 & 19 & Makwanpur & 3 & 2 & & & \\
\hline & Dadeldhura & 2 & 2 & Gorkha & 6 & 36 & & & \\
\hline & Baitadi & - & 1 & Lamjung & 7 & 23 & & & \\
\hline & & & & Tanahau & 2 & 2 & & & \\
\hline & & & & Syangja & 3 & 4 & & & \\
\hline & & & & Kaski & 13 & 29 & & & \\
\hline & & & & Myagdi & - & 33 & & & \\
\hline & & & & Parbat & 2 & 5 & & & \\
\hline & & & & Baglung & 4 & 60 & & & \\
\hline & & & & Gulmi & 3 & 11 & & & \\
\hline & & & & Palpa & 4 & 12 & & & \\
\hline & & & & Arghakhanchi & 1 & 3 & & & \\
\hline & 11 & 15 & 190 & 20 & 58 & 269 & 8 & 32 & 86 \\
\hline \multirow{11}{*}{ 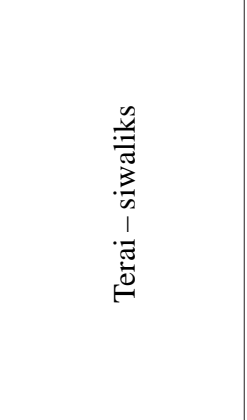 } & Kapilbastu & 9 & 351 & Dhanusa & - & 230 & Jhapa & 3 & 136 \\
\hline & Dang & 1 & 38 & Mahottari & - & 186 & Morang & 1 & 184 \\
\hline & Banke & - & 243 & Sarlahi & - & 74 & Sunsari & 1 & 69 \\
\hline & Bardiya & 3 & 82 & Rautahat & 3 & 85 & Saptari & - & 46 \\
\hline & Kailali & 4 & 114 & Bara & - & 93 & Siraha & - & 140 \\
\hline & Kanchanpur & 5 & 85 & Parsa & - & 71 & & & \\
\hline & & & & Chitawan & - & 40 & & & \\
\hline & & & & Nawalparasi & - & 163 & & & \\
\hline & & & & Rupandehi & 4 & 289 & & & \\
\hline & 6 & 22 & 913 & 9 & 7 & 1231 & 5 & 5 & 575 \\
\hline & 24 & 69 & 1810 & 35 & 113 & 2009 & 16 & 96 & 1539 \\
\hline
\end{tabular}

Note: Clustering of districts in the Phytogeographical Regions and Ecological Zones are based on distribution of areas. Sources: District Maps (D), Topographical Sheets (T) 
Ukesh Raj Bhuju et al./A Map Based Inventory.

A complete list of 5,358 lakes along with the basic information are compiled and maintained as a baseline for the lake database. The lists were distributed among the key partner institutions, namely NAST, NTNC, TUCDES and the Central Department of Statistics of the Government of Nepal, amidst a function of the National Workshop on Lakes Conservation and Development Strategic Plan Preparation held on December 29, 2009 in Lalitpur, Nepal.

Of the 75 districts of the country, 74 contain lakes. Although the district map of Okhaldhunga indicates two lakes, there are none on the topographical sheets of the district. There are 21 districts containing less than nine lakes in each, and 16 districts containing over 100 lakes in each. Among the rest of the districts, 16 contain 10 to 29 lakes, and 22 contain 30 to 99 lakes (Fig. 3).

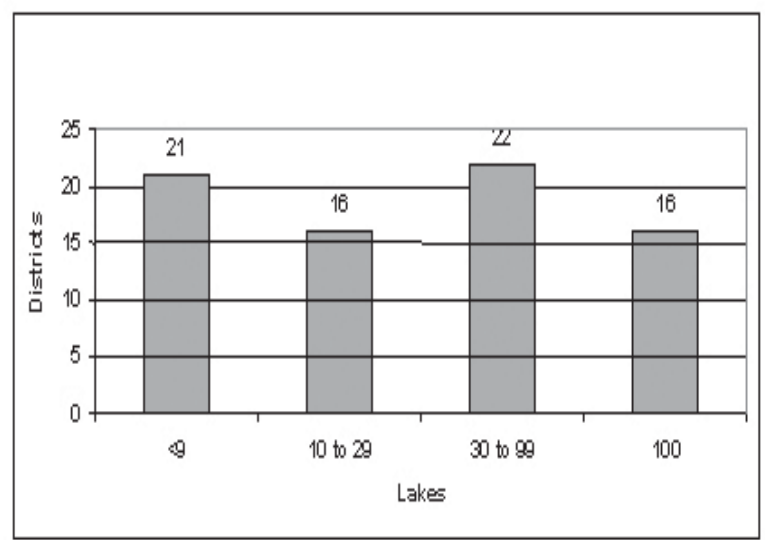

Fig. 3. Number of lakes and districts

The eight districts containing high number of lakes are Humla (381), Taplejung (380), Kapilbastu (351), Solukhumbu (339), Rupandehi (289), Banke (243), Dhanusa (230), and Dolpa (210).

Altitude wise, 2,712 lakes (51\%) are distributed below 500m, and 2,227 (42\%) above 3,000m. Only 419 lakes $(<8 \%)$ are in the mid hills of altitudinal range between 500m and 2,999m (Table 2).

The number of lakes having their names mentioned in the topographical sheets is 472 which are $9 \%$ of the total number of lakes. Of these named lakes, $60 \%$ lie above $4,000 \mathrm{~m}$ altitude, $18 \%$ below $499 \mathrm{~m}$ altitude.

Table 2. Altitudinal distribution of lakes in Nepal

\begin{tabular}{|c|c|c|c|}
\hline \multirow{2}{*}{ Altitude } & \multicolumn{3}{|c|}{ Lakes } \\
\hline & & Number & $\%$ \\
\hline Below 100 & 1270 & & \\
\hline $100-499$ & 1442 & 2712 & 50.62 \\
\hline 500-999 & 77 & & \\
\hline 1000-1499 & 69 & & \\
\hline 1500-1999 & 125 & 419 & 782 \\
\hline $2000-2499$ & 114 & & \\
\hline 2500-2999 & 34 & & \\
\hline 3000-3499 & 56 & & \\
\hline 3500-3999 & 60 & & \\
\hline 4000-4499 & 418 & 2227 & 41.56 \\
\hline 4500-4999 & 762 & & \\
\hline $5000-5499$ & 764 & & \\
\hline above 5500 & 167 & & \\
\hline Total & 5358 & 5358 & 100.00 \\
\hline
\end{tabular}

Among the notable lakes of the country, the Rara lake is the largest one covering an area of 800ha, and Phoksundo is the longest one with its length $5.15 \mathrm{~km}$. Similarly, the Dhau Dhundhun Tal is the highest placed lake in Mustang at an altitude of 5905m, and a lake near Musahamiyatol in Mukhiya Patti VDC, Dhanusha is at 59m altitude (Boxes 1-4, and Fig. 4-7).

(Note: The maps shown in the figures are images of the parts of the topographical sheets, and are not necessarily to the scale).

\section{Acknowledgements}

Participants of the appreciative inquiries, consultative workshops and meetings, and focus group discussions, Researchers of the International Union for Nature Conservation (IUCN) Nepal Office, the Nepal Academy of Sciences and Technology (NAST), the National Trust for Nature Conservation (NTNC), and the Tribhuvan University - Central Department of Environmental Science (TU-CDES), and Board members of the NLCDC. 


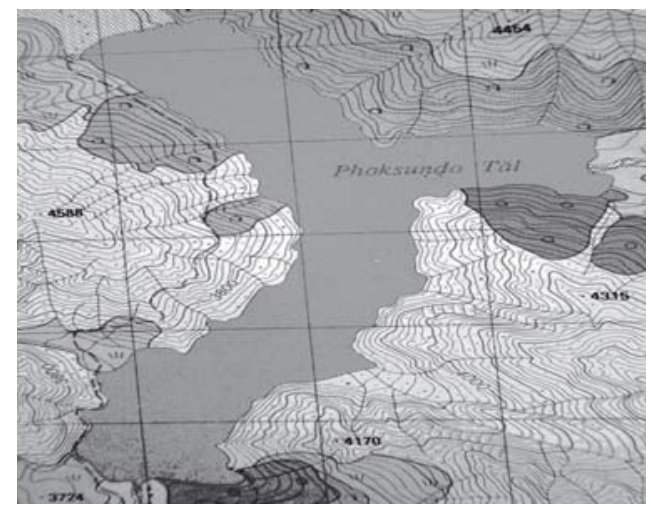

Fig. 4. Lake Phoksundo

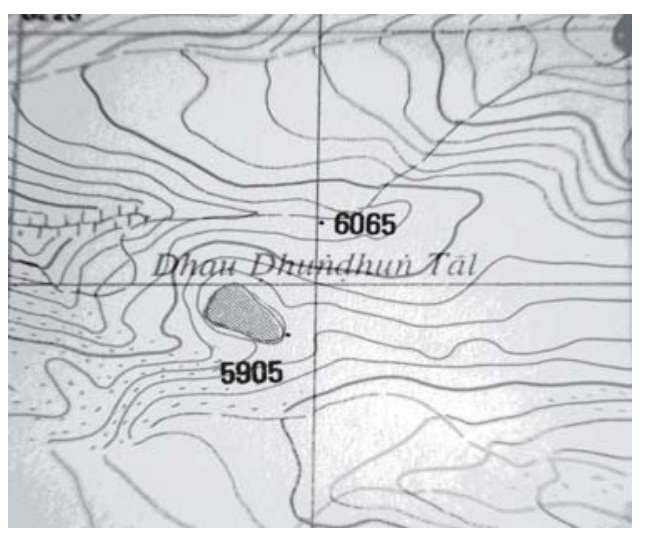

Fig. 5. Lake Dhau Dhundhun

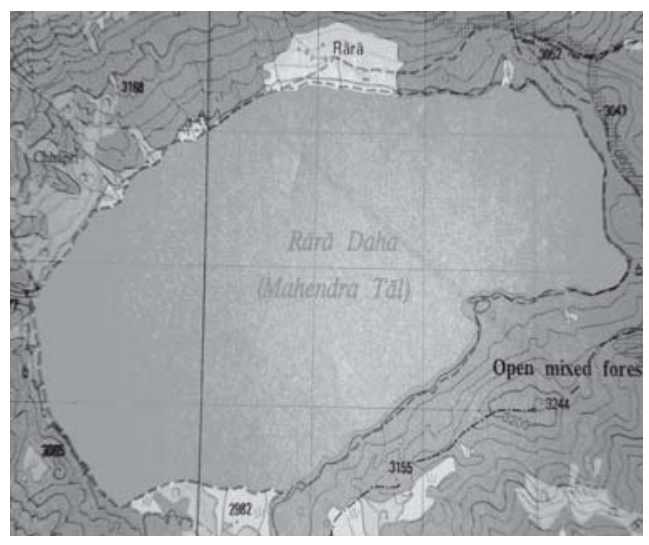

Fig. 6. Lake Rara

\section{Box 1. Longest Lake Phoksundo}

Name of Lake:

Topo-sheet no:

Phoksundo Tal

Code:

2982-16

District:

DP70

VDC:

Nearby City/Village:

Area:

Phoksundo

Length:

Rigmo (0.8Km)

Breadth:

Altitude:

$5.15 \mathrm{Km}$

$1.1 \mathrm{Km}$

$3620 \mathrm{~m}$

\begin{tabular}{ll|}
\hline \multicolumn{2}{|c|}{ Box 2. High Altitude Lake } \\
Name of Lake: & Dhau Dhundhun Tal \\
Topo- Sheet no: & $2983-16$ \\
Code: & MS52 \\
District: & Mustang \\
VDC: & Charan \\
Nearby City/Village: & Saukre (20Km) \\
Area: & $4.75 h a$ \\
Length: & $350 \mathrm{~m}$ \\
Breadth: & $150 \mathrm{~m}$ \\
Perimeter: & $900 \mathrm{~m}$ \\
Altitude: & $5905 \mathrm{~m}$ \\
\hline
\end{tabular}

\begin{tabular}{ll|}
\multicolumn{2}{c|}{ Box 3. Largest Lake } \\
Name of Lake: & Rara \\
Topo-sheet no: & 2982- 05 \\
Code: & MU12 \\
District: & Mugu \\
VDC: & Rara \\
Nearby City/Village: & Rara (0Km) \\
Area: & 800ha \\
Length: & $5 \mathrm{Km}$ \\
Breadth: & $2 \mathrm{Km}$ \\
Perimeter: & $9 \mathrm{Km}$ \\
Altitude: & $3060 \mathrm{~m}$ \\
\hline
\end{tabular}




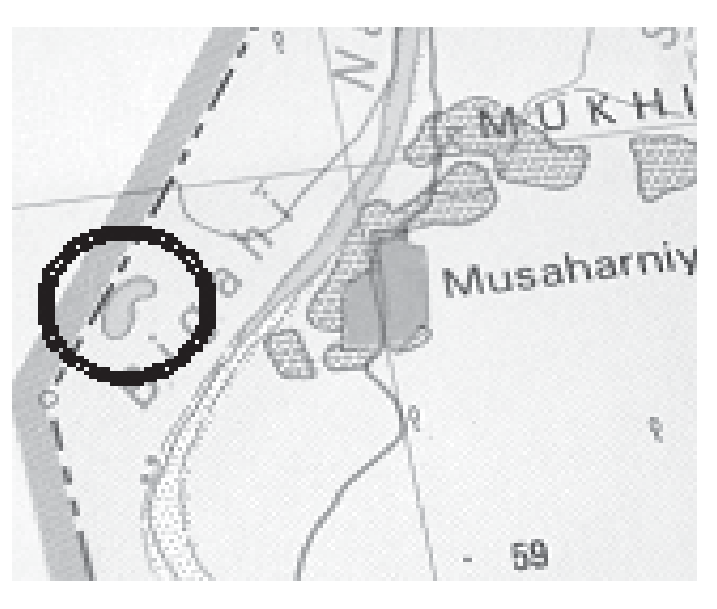

Fig. 7. Lake near Musahamiyatol

\section{References}

Answers Corporation. 2009. Lakes. http:// www.answers.com/topic/lake, October 29, 2009.

CBD. 2006. Guidelines for the rapid ecological assessment of biodiversity in inland water, coastal and marine areas. Secretariat of the Convention on Biological Diversity,Montreal, Canada, CBD Technical Series no. 22 and the Secretariat of the Ramsar Convention, Gland, Switzerland, Ramsar Technical Report no. 1. www.cbd.int/doc/publications/cbd-ts-22.pdf

DOAD. 1993. National fisheries development plan-1992/ 93. Fisheries Development Division, Department of Agriculture Development, HMGN, Kathmandu, Nepal.

Downing, J.A., Y.T. Prairie, J.J. Cole, C.M. Duarte, L.J. Tranvick, R.G. Striegel, W.H. McDowell, P.

\begin{tabular}{|ll|}
\hline \multicolumn{2}{|c|}{ Box 4. Low Altitude Lake } \\
Name of Lake: & $\mathrm{X}$ \\
(near Boundary Pillar 53) & \\
Topo- Sheet no: & 2685-08C \\
Code: & DS65 \\
District: & Dhanusha \\
VDC: & Mukhiya Patti \\
Nearby City/Village: & Musahamiyatol (1.5Km) \\
Area: & $0.5 h a$ \\
Length: & $125 \mathrm{~m}$ \\
Breadth: & $50 \mathrm{~m}$ \\
Perimeter: & $425 \mathrm{~m}$ \\
Altitude: & $59 \mathrm{~m}$ \\
\hline
\end{tabular}

Kortelainen, J.M. Melack and J.J. Middleburg. 2006. The global abundance and size distribution of lakes, ponds and impoundments. Limnology and Oceanography 51:2388-2397.

IUCN-Nepal. 1996. An Inventory of Nepal's wetlands. IUCN-Nepal, Kathmandu.

Jha, P.K. and P. Lacoul. 1998. Wetlands in Nepal: Status, significance and management. In: (Eds. S.K Majumdar, E.W. Miller and F.J. Brenner. Ecology of wetlands and associated systems. pp. 648- 669. The Pennsylvania Academy of Science, USA.

Mool, P., S.R. Bajracharya. and S.P. Joshi. 2001. Inventory of glaciers, glacial lakes and glacial lake outburst floods: monitoring and early warning systems in the Hindu Kush-Himalayan region - Nepal. ICIMOD, Kathmandu. 
Nepal Journal of Science and Technology 11 (2010) 173-180 